\title{
Identification of Saccharomonospora Strains by the Use of Genomic DNA Fragments and rRNA Gene Probes
}

\author{
JUNG-HOON YOON, ${ }^{1,2}$ HONGIK KIM, ${ }^{1}$ SAM-BONG KIM, ${ }^{3}$ HONG-JOONG KIM, ${ }^{1,4}$ WON YONG KIM, ${ }^{1}$ \\ SUNG TAIK LEE, ${ }^{2}$ MICHAEL GOODFELLOW, ${ }^{3}$ AND YONG-HA PARK ${ }^{*}$ \\ Bioinformatics \& Systematics Laboratory, Korean Collection for Type Cultures, Korea Research Institute of Bioscience and \\ Biotechnology, Korea Institute of Science and Technology, Daeduk Science Park, ${ }^{1}$ and Department of Biological Science, \\ Korea Advanced Institute of Science and Technology, ${ }^{2}$ Taejeon, and Daesung Microbiology Institute Co., Seoul, ${ }^{4}$ \\ Republic of Korea, and Department of Microbiology, The Medical School, University of Newcastle \\ upon Tyne, Newcastle upon Tyne, NE2 4HH, United Kingdom ${ }^{3}$
}

\begin{abstract}
Restriction digestion fragments of DNAs extracted from 14 representative strains of Saccharomonospora azurea, "Saccharomonospora caesia," Saccharomonospora cyanea, Saccharomonospora glauca, and Saccharomonospora viridis and six "Saccharomonospora"-like isolates were separated by electrophoresis, Southern blotted onto nylon membranes, and hybridized by using two rRNA gene probes cloned from Streptomyces griseus subsp. griseus KCTC 9080. The following four restriction endonucleases were used: Bam HI, SalI, PvuII, and Xhol. The resultant five ribotype patterns were considered species specific. The genomic diversity revealed by ribotyping indicates that this method can be used to both characterize and identify saccharomonosporae. All of the test strains contained DNA with three rRNA gene clusters.
\end{abstract}

The genus Saccharomonospora was proposed by Nonomura and Ohara (21) for aerobic, gram-positive, non-acid-fast, nonmotile, monosporic actinomycetes which typically form nonfragmenting, branched substrate mycelia with walls that contain meso-diaminopimelic acid, arabinose, and galactose (wall chemotype IV sensu Lechevalier and Lechevalier [20]). Additional chemical markers include the presence of major amounts of iso and anteiso fatty acids, 2-hydroxy fatty acids, phosphatidylethanolamine, and tetrahydrogenated menaquinones with nine isoprene units (17). This genus forms a distinct clade within the evolutionary radiation encompassed by the family Pseudonocardiaceae (16).

There are currently four validly described Saccharomonospora species, namely, Saccharomonospora azurea Runmao 1987 (23), Saccharomonospora cyanea Runmao and Guizhen 1988 (24), Saccharomonospora glauca Greiner-Mai et al. 1988 (8), and Saccharomonospora viridis Nonomura and Ohara 1970 (21), the type species of the genus. A fifth taxon, "Saccharomonospora caesia," was proposed by Greiner-Mai et al. (9) for strains previously classified as Micropolyspora caesia Kalakoutskii $(12,17)$; this name was not included on the Approved Lists of Bacterial Names (25) and has not been validly published. However, reliable procedures are still needed to distinguish validly published and putatively novel Saccharomonospora species. It is important to distinguish Saccharomonospora species as some strains are agents of hypersensitivity pneumonitis (18). Saccharomonospora viridis has been strongly implicated as a causal agent of farmer's lung disease $(1,7)$.

Improvements in the classification of the genus Saccharomonospora have made it possible to choose good representative strains for comparative taxonomic studies. Thus, in a comprehensive numerical taxonomic survey, Kim equated numerically circumscribed clusters with Saccharomonospora azurea, "Saccharomonospora caesia," Saccharomonospora cyanea, Saccharomonospora glauca and Saccharomonospora viridis (15). It is also encouraging that representatives of validly described and putatively novel Saccharomonospora species can be

* Corresponding author. Phone: 82-42-860-4620. Fax: 82-42-8604625. Electronic mail address: yhpark@gerigw.geri.re.kr. separated on the basis of 16S rRNA gene (rDNA) sequence data (16) although Saccharomonospora azurea $\mathrm{K} 161^{\mathrm{T}}(\mathrm{T}=$ type strain) and "Saccharomonospora caesia" K163 have been shown to have identical 16S rRNA gene sequences.

Recent advances in nucleic acid fingerprinting techniques have been found to be effective as rapid and specific aids in the characterization and identification of bacterial species that are difficult to identify (27). In particular, species- and strain-specific ribosomal restriction endonuclease patterns can be visualized after hybridization of rRNA gene probes to genomic DNAs isolated from members of diverse bacterial genera (10). Species-specific differences in ribotype patterns have been used to identify several bacterial species for which conventional laboratory identification methods are inadequate. This method has been used in actinomycete systematics, notably with respect to the genera Actinomyces $(2,5)$, Corynebacterium (26), Gordona (22), Mycobacterium (4, 13), Rhodococcus (19), and Streptomyces (6).

The primary aim of this investigation was to determine the value of ribotyping in the classification and identification of Saccharomonospora species. To this end, two rDNA probes were used to determine rRNA operon-targeted polymorphisms in 20 judiciously chosen representatives of the genus Saccharomonospora. The resultant data were also used to determine the copy numbers of the rRNA gene clusters in the test strains.

\section{MATERIALS AND METHODS}

Organisms and culture conditions. The test strains (Table 1) were grown in shake fiasks containing tryptone soy broth supplemented with glucose $0.75 \%$, $\mathrm{wt} / \mathrm{vol}$ ) at $45^{\circ} \mathrm{C}$ for $48 \mathrm{~h}$. The broth cultures were checked for purity before they were harvested by centrifugation.

Extraction of DNA. Chromosomal DNA was extracted and purified by using a previously described procedure (11). Wet biomass (ca. $3 \mathrm{~g}$ ) was suspended in 10 $\mathrm{ml}$ of TE buffer (10 mM Tris-HCl, 1 mM EDTA; $\mathrm{pH} 8.0)$ supplemented with lysozyme $(10 \mathrm{mg} / \mathrm{ml})$ and incubated for $15 \mathrm{~min}$ at $37^{\circ} \mathrm{C}$ before $1 \mathrm{ml}$ of $20 \%$ (wt/vol) sodium dodecyl sulfate (SDS), $10 \mathrm{ml}$ of Tris-HCl ( $\mathrm{pH} 8.0$ )-saturated phenol, and $1.5 \mathrm{ml}$ of $5 \mathrm{M} \mathrm{NaCl}$ were added. The resulting preparation was centrifuged at $5,000 \times g$ for $10 \mathrm{~min}$, the supernatant was extracted twice with an equal volume of chloroform, and the crude DNA precipitate was recovered with an equal volume of isopropanol. The chromosomal DNA was resuspended in 10 $\mathrm{ml}$ of TE buffer and incubated first with RNase A $(20 \mu \mathrm{g} / \mathrm{ml}$; Sigma) for $60 \mathrm{~min}$ at $50^{\circ} \mathrm{C}$ and then with proteinase $\mathrm{K}\left(100 \mu \mathrm{g} / \mathrm{ml}\right.$; Sigma) for $60 \mathrm{~min}$ at $37^{\circ} \mathrm{C}$. 
TABLE 1. Designations and sources of test strains

\begin{tabular}{|c|c|c|}
\hline Laboratory no. ${ }^{a}$ & Taxon & Other designation(s) and/or source ${ }^{b}$ \\
\hline $\mathrm{K} 161^{\mathrm{T}}$ & Saccharomonospora azurea & $\begin{array}{l}\text { H. Runmao NA-128 (SIIA 86128); Sichuan Industrial Institute of Antibiotics, } \\
\text { Chengdu, Sichuan, People's Republic of China }\end{array}$ \\
\hline K163 & "Saccharomonospora caesia" & DSM 43068, CCM 3262, R. Hütter ETH 28747, Corbaz 168; moldy hay \\
\hline K182 & "Saccharomonospora caesia" & $\begin{array}{l}\text { E. Greiner-Mai Ko18; Institut für Mikrobiologie, Technische Hochschule, } \\
\text { Darmstadt, Germany }\end{array}$ \\
\hline K200 & "Saccharomonospora caesia" & $\begin{array}{l}\text { J. Lacey A1932, Plant Pathology Department, Rothamsted Experimental Station, } \\
\text { Harpenden, United Kingdom }\end{array}$ \\
\hline $\mathrm{K} 168^{\mathrm{T}}$ & Saccharomonospora cyanea & $\begin{array}{l}\text { H. Runmao NA-134 (SIIA 86134); soil, Guangyuan City, People's Republic of } \\
\text { China }\end{array}$ \\
\hline $\mathrm{K} 169^{\mathrm{T}}$ & Saccharomonospora glauca & DSM 43769 \\
\hline K179 & Saccharomonospora glauca & $\begin{array}{l}\text { A. J. McCarthy BD-125; hay, Department of Genetics and Microbiology, } \\
\text { University of Liverpool, Liverpool, and Rothamsted Experimental Station, } \\
\text { Harpenden, United Kingdom }\end{array}$ \\
\hline K194 & Saccharomonospora glauca & $\begin{array}{l}\text { J. Lacey A66; hay, Rothamsted Experimental Station, Harpenden, United } \\
\text { Kingdom }\end{array}$ \\
\hline K195 & Saccharomonospora glauca & J. Lacey A1450; air sample, cotton mill, Cramlington, United Kingdom \\
\hline K202 & Saccharomonospora glauca & J. Ruan 350; Institute of Microbiology, Beijing, People's Republic of China \\
\hline $\mathrm{K} 73^{\mathrm{T}}$ & Saccharomonospora viridis & NCIB 9602, E. Küster P101; peat, Ireland \\
\hline K185, K191 & Saccharomonospora viridis & E. Greiner-Mai L1v and R25 \\
\hline K197 & Saccharomonospora viridis & J. Lacey A1905; mushroom compost, Avon, United Kingdom \\
\hline SB-01, SB-22, SB-58 & "Saccharomonospora"-like isolates & S.-B. Kim, mushroom compost, Somerset, United Kingdom \\
\hline SB-31, SB-33, SB-37 & "Saccharomonospora"-like isolates & S.-B. Kim, hay, Rothamsted Experimental Station, Harpenden, United Kingdom \\
\hline
\end{tabular}

${ }^{a}$ The $16 \mathrm{~S}$ rRNA sequences of strains K161 ${ }^{\mathrm{T}}, \mathrm{K} 163, \mathrm{~K} 168^{\mathrm{T}}, \mathrm{K} 169^{\mathrm{T}}$, K202, K73, K191, SB-01, SB-22, SB-58, SB-33, and SB-37 were determined by Kim et al. (16).

${ }^{b}$ Abbreviations: CCM, Czechoslovak Collection of Microorganisms, Masaryk University, Brno, Czech Republic; DSM, Deutsche Sammlung von Mikroorganismen, Braunschweig, Germany; NCIB, National Collection of Industrial and Marine Bacteria, Ltd., Aberdeen, United Kingdom.

Following this the DNA was extracted once with phenol and twice with chloroform. It was then precipitated with isopropanol, spooled out with a glass rod, dried, and resuspended in TE buffer. The concentration and quality of each DNA preparation were determined spectrophotometrically and by agarose gel electrophoresis.

Preparation and labelling of probes. The PCR was used to amplify an 899-bp region close to the $5^{\prime}$ end of the 16S rDNA (positions 4 to 902 [Streptomyces griseus subsp. griseus KCTC 9080 16S rRNA numbering]) and a 660-bp region close to the $3^{\prime}$ end of the 23S rDNA (positions 2154 to 2813 [Streptomyces griseus subsp. griseus KCTC $908023 \mathrm{~S}$ rRNA numbering]) from the $r n E$ gene cluster of Streptomyces griseus subsp. griseus KCTC 9080 . The probes were labelled by using a nonradioactive ECL direct nucleic acid labelling and detection system (Amersham International plc, Buckinghamshire, United Kingdom) and the manufacturer's instructions.

Southern blotting and hybridization. Aliquots $(2 \mu \mathrm{g})$ of the chromosomal DNAs of the test strains were digested with 4 U of BamHI, Sall, PvuII, and XhoI overnight at $37^{\circ} \mathrm{C}$ as recommended by the manufacturer (Boehringer Mannheim GmbH Biochemica, Mannheim, Germany). Chromosomal DNA from Saccharomonospora glauca $\mathrm{K} 169^{\mathrm{T}}$ was also digested with $\mathrm{BglII}$ by the same procedure. Restriction nuclease fragments were then separated by electrophoresis in a $0.7 \%$ (wt/vol) agarose gel in Tris-acetate buffer $(0.04 \mathrm{M}$ Tris-acetate, $0.001 \mathrm{M}$ EDTA). The separated DNA fragments were denatured in the gel, transferred to a nylon membrane (Hybond $\mathrm{N}+$; Amersham International plc), fixed with UV light for $3 \mathrm{~min}$, and then hybridized in tubes in an oven (model HB-OV-BL/Bs; Hybaid, Ltd., Middlesex, United Kingdom). Prehybridization was performed in a hybridization solution (ECL direct nucleic acid labelling and detection system; Amersham International plc) for $1 \mathrm{~h}$. One of the two labelled probes was added to the hybridization solution, and the preparation was incubated for $8 \mathrm{~h}$ at $42^{\circ} \mathrm{C}$. Following hybridization, the membrane was washed once with a primary working solution $\left(0.1 \times \mathrm{SSC}, 0.4 \%\right.$ [wt/vol] SDS) for $10 \mathrm{~min}$ at $55^{\circ} \mathrm{C}$ and once with a secondary working solution $(2 \times \mathrm{SSC})$ for $5 \mathrm{~min}$ at room temperature $(1 \times \mathrm{SSC}$ is $0.15 \mathrm{M} \mathrm{NaCl}$ plus $0.015 \mathrm{M}$ sodium citrate). The hybrids on the membrane were detected by using detection reagents (ECL direct nucleic acid labelling and detection system; Amersham International plc). Hybridization with the second probe was carried out with the same preparation by using the same conditions once the probe hybridized on the membrane in the first experiment had been eliminated by stringent agitation with reprobing solution $(0.2 \mathrm{~N} \mathrm{NaOH}, 0.1 \%$ [wt/vol] SDS) for $30 \mathrm{~min}$ at $65^{\circ} \mathrm{C}$.

\section{RESULTS AND DISCUSSION}

DNA samples were checked for the absence of extensive shearing and degradation prior to digestion with the restriction
A

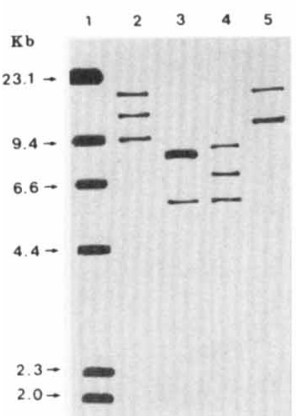

B

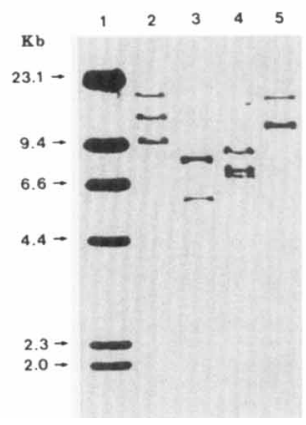

C

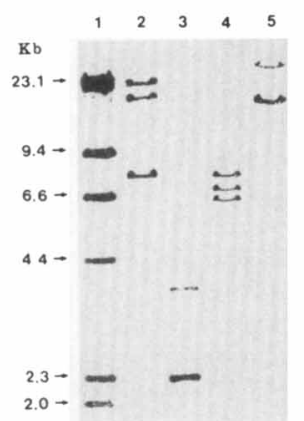

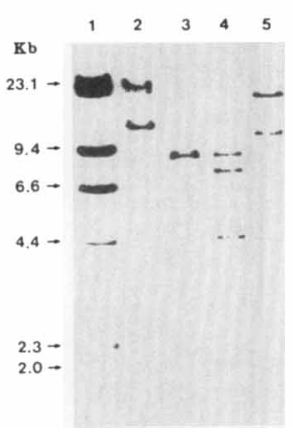

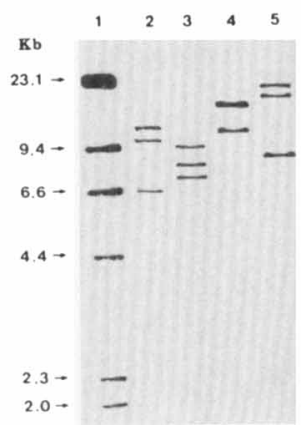

FIG. 1. Ribotype patterns generated from DNA digests of representative Saccharomonospora strains hybridized with the 5 ' end probe of $16 \mathrm{~S}$ rDNA from Streptomyces griseus subsp. griseus KCTC 9080. The strains used were Saccharomonospora azurea K161" (A), "Saccharomonospora caesia" K163 (B), Saccharomonospora cyanea $\mathrm{K} 168^{\mathrm{T}}$ (C), Saccharomonospora glauca $\mathrm{K} 169^{\mathrm{T}}$ (D), and Saccharomonospora viridis K $73^{\mathrm{T}}$ (E). Lanes 1 , molecular weight markers (restriction fragments of bacteriophage $\lambda$ DNA digested with HindIII); lanes 2, BamHI digests; lanes 3, SalI digests; lanes 4, XhoI digests; lanes 5, PvuII digests. 

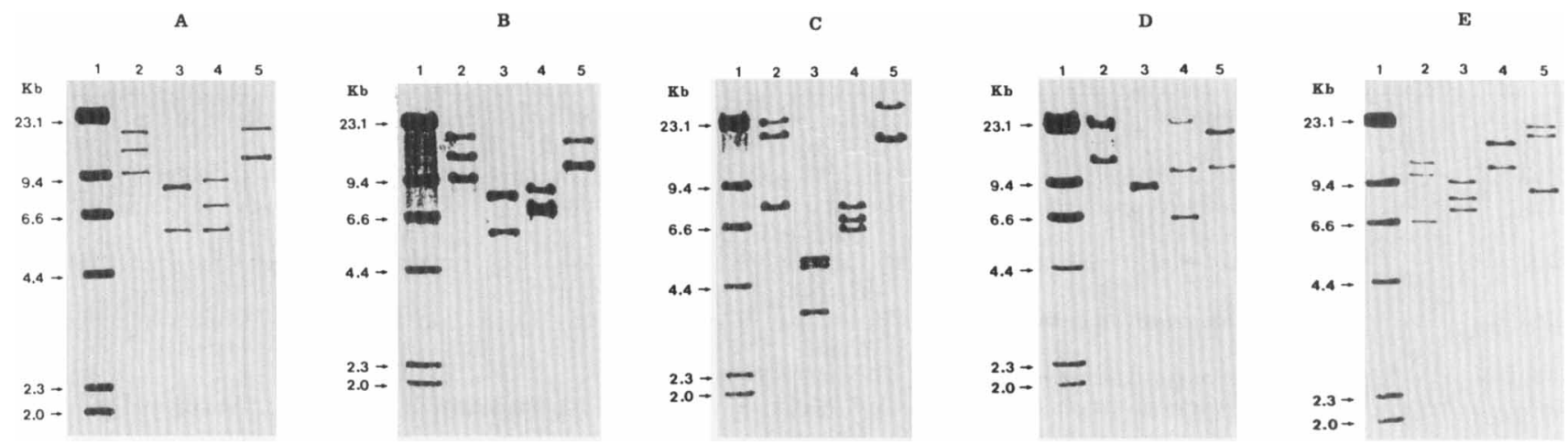

FIG. 2. Ribotype patterns generated from DNA digests of representative Saccharomonospora strains hybridized with the $3^{\prime}$ end probe of $23 \mathrm{~S}$ rDNA from Streptomyces griseus subsp. griseus KCTC 9080. The strains used were Saccharomonospora azurea $\mathrm{K} 161^{\mathrm{T}}$ (A) "Saccharomonospora caesia" K163 (B), Saccharomonospora cyanea $\mathrm{K} 168^{\mathrm{T}}(\mathrm{C})$, Saccharomonospora glauca $\mathrm{K} 169^{\mathrm{T}}$ (D), and Saccharomonospora viridis K73 ${ }^{\mathrm{T}}$ (E). Lanes 1, molecular weight markers (restriction fragments of bacteriophage $\lambda$ DNA digested with HindIII); lanes 2, BamHI digests; lanes 3, SalI digests; lanes 4, XhoI digests; lanes 5, PvuII digests.

enzymes and after electrophoresis of the genomic digests. The DNA preparations had high molecular weights and were free from the products of extensive shearing. The absence of highmolecular-weight DNA in the agarose gel electrophoretic patterns of the genomic digests showed that the DNA samples were completely digested. The restriction fragment length polymorphisms of the ribosomal genes of the representative strains of Saccharomonospora azurea, "Saccharomonospora caesia," Saccharomonospora cyanea, Saccharomonospora glauca, and Saccharomonospora viridis allow these taxa to be distinguished (Fig. 1 and 2). The additional "Saccharomonospora caesia," Saccharomonospora glauca, and Saccharomonospora viridis strains produced ribotype patterns identical to those of the corresponding representative strains. Interestingly, isolates SB-01, SB-22, and SB-58 produced ribotype patterns identical to the pattern produced by the representative strain of "Saccharomonospora caesia," SB-37 produced a pattern identical to the pattern produced by the representative strain of Saccharomonospora glauca, and SB-31 and SB-33 produced patterns identical to the pattern produced by the representative strain of Saccharomonospora viridis.

The same ribotype patterns were produced by the Saccharomonospora azurea, "Saccharomonospora caesia," and Saccharomonospora viridis strains irrespective of which of the probes was used, indicating that the four restriction enzymes did not digest either the structural genes or the interspacer regions of the rRNA operons (Fig. 1 and 2). In contrast, different ribotype patterns were produced when the XhoI digests of the Saccharomonospora glauca strains were treated with the two rDNA probes. It seems that these strains have an XhoI site(s) in either the structural genes or the interspacer regions of the rRNA operons. Similarly, Saccharomonospora cyanea $\mathrm{K} 168^{\mathrm{T}}$ appears to have a SalI site(s) in one of the two regions of the rRNA operons. Similar results have been obtained with $16 \mathrm{~S}$ and 23S rRNA probes (3).

Saccharomonospora azurea $\mathrm{K} 161^{\mathrm{T}}$ and the "Saccharomonospora caesia" strains produced identical ribotype patterns when the products of the BamHI, SalI, and PvuII digests were treated with the rDNA probes. However, in corresponding studies performed with XhoI digests, Saccharomonospora azurea $\mathrm{K} 161^{\mathrm{T}}$ could be differentiated from the "Saccharomonospora caesia" strains (Fig. 1 and 2). Previously, members of these taxa were found to be closely related in numerical phenetic (15) and 16S rRNA sequencing studies (16). DNA-DNA relatedness experiments are needed to determine the exact taxonomic relationship between Saccharomonospora azurea and "Saccharomonospora caesia" before a new taxon can be validly described. It is also interesting that the Saccharomonospora azurea, "Saccharomonospora caesia," Saccharomonospora cyanea, Saccharomonospora glauca, and Saccharomono-
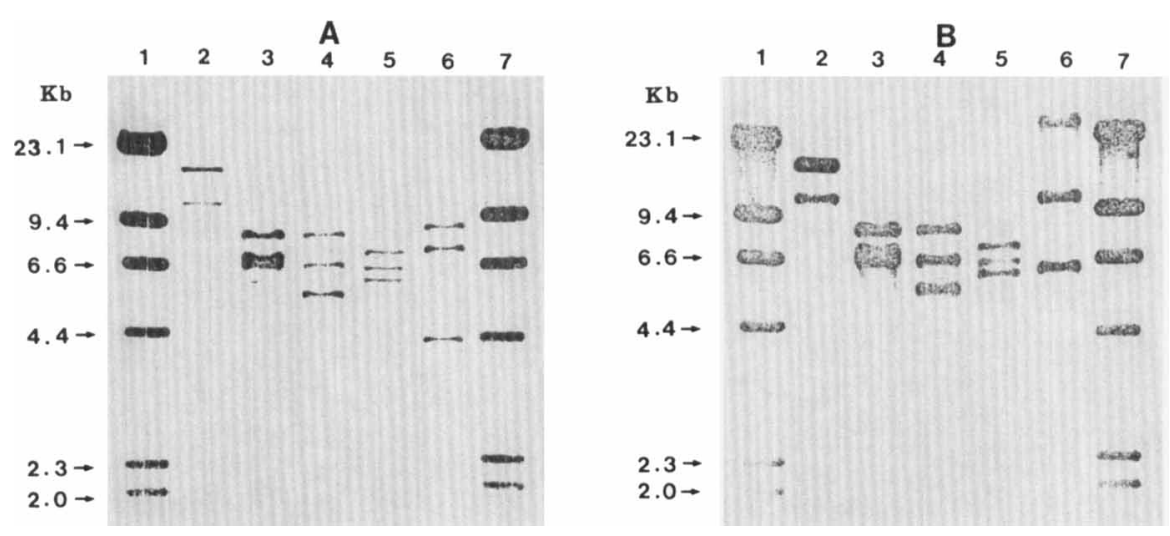

FIG. 3. Ribotype analysis of XhoI-digested DNAs from representative Saccharomonospora strains. (A) Hybridization with the 5' end probe of $16 \mathrm{~S}$ rDNA from Streptomyces griseus subsp. griseus KCTC 9080. (B) Hybridization with the 3' end probe of 23S rDNA from Streptomyces griseus subsp. griseus KCTC 9080. Lanes 1 and 7, molecular weight markers (restriction fragments of bacteriophage $\lambda$ DNA digested with HindIII); lanes 2, Saccharomonospora viridis K $73^{\mathrm{T}}$; lanes 3 , "Saccharomonospora caesia" K163; lanes 4, Saccharomonospora azurea K161 ${ }^{\mathrm{T}}$; lanes 5, Saccharomonospora cyanea K168 ${ }^{\mathrm{T}}$; lanes 6, Saccharomonospora glauca K169 ${ }^{\mathrm{T}}$. 


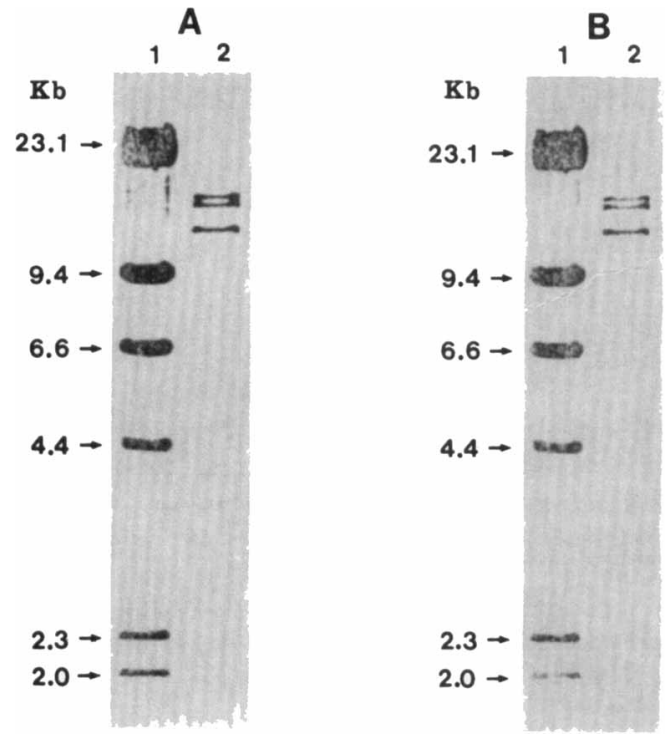

FIG. 4. Ribotype analysis of BglII-digested DNA from Saccharomonospora glauca $\mathrm{K} 169^{\mathrm{T}}$. (A) Hybridization with the $5^{\prime}$ end probe of $16 \mathrm{~S}$ rDNA from Streptomyces griseus subsp. griseus KCTC 9080. (B) Hybridization with the 3 ' end probe of $23 \mathrm{~S}$ rDNA from Streptomyces griseus subsp. griseus KCTC 9080 . Lanes 1 , molecular weight markers (restriction fragments of bacteriophage $\lambda$ DNA digested with HindIII); lanes 2, Saccharomonospora glauca $\mathrm{K} 169^{\mathrm{T}}$.

spora viridis strains produced distinct ribotype patterns when XhoI digests were treated with the rRNA probes (Fig. 3).

The number of bands and their relative intensities indicate that the chromosomes of the Saccharomonospora azurea, "Saccharomonospora caesia," Saccharomonospora cyanea, and Saccharomonospora viridis strains contain three rRNA gene clusters. In contrast, the Saccharomonospora glauca strains gave ambiguous results when the Bam HI and PvuII digests were probed (Fig. 1 and 2). However, we found that Saccharomonospora glauca $\mathrm{K} 169^{\mathrm{T}}$ also contains three rRNA gene clusters when $B g l$ II digests were treated with the two rDNA probes (Fig. 4). There is evidence that the copy number of rRNA genes may provide taxonomically useful information $(2,4)$.

We concluded that the ribotyping method in which four restriction endonucleases are used provides a useful and reliable way to distinguish Saccharomonospora azurea, "Saccharomonospora caesia," Saccharomonospora cyanea, Saccharomonospora glauca, and Saccharomonospora viridis strains. The five ribotype patterns which we obtained can be considered species specific as members of these taxa formed distinct taxospecies in the comprehensive numerical taxonomic study of Kim et al. (14). In theory, members of these taxa can be distinguished merely by probing $X h o I$ digests with the rDNA probes. However, in practice, the remaining restriction enzymes should be used in order to help ensure the detection of members of putatively novel Saccharomonospora species.

\section{ACKNOWLEDGMENTS}

This work was supported by grants N-81550, F-80500, and F-80370 from the Ministry of Science and Technology of the Republic of Korea.

We are also grateful to $R$. M. Kroppenstedt for providing strains.

\section{REFERENCES}

1. Barrowcliff, D. E., and P. G. Arblaster. 1968. Farmer's lung: a study of an early acute fatal case. Thorax 23:490-500.
2. Barsotti, O., D. Decoret, G. Benay, A. Carlotti, J. Freney, V. Guerin-Faublee, and J.-J. Morrier. 1994. rRNA gene restriction patterns as possible taxonomic tools for the genus Actinomyces. Zentralbl. Bakteriol. Parasitenkd. Infektionskr. Hyg. Abt. 1 Orig. 281:433-441.

3. Baylis, H. A., and M. J. Bibb. 1988. Organisation of the ribosomal RNA genes in Streptomyces coelicolor A3(2). Mol. Gen. Genet. 211:191-196.

4. Bercovier, H., O. Kafric, and S. Sala. 1986. Mycobacteria possess a surprisingly small number of ribosomal RNA genes in relation to the size of their genome. Biochem. Biophys. Res. Commun. 136:1136-1141.

5. Bowden, G., J. Johnson, and C. Schachtele. 1993. Characterization of Actinomyces with genomic DNA fragments and rRNA gene probes. J. Dent. Res. 72:1171-1179.

6. Doering-Saad, C., P. Kämpfer, S. Manulis, G. Kritzman, J. Schneider, J. Zakrzewska-Czerwinska, H. Schrempf, and I. Barash. 1992. Diversity among Streptomyces strains causing potato scab. Appl. Environ. Microbiol. 58:39323940.

7. Greene, J. G., M. W. Treuhaft, and R. M. Arnsell. 1981. Hypersensitivity pneumonitis due to Saccharomonospora viridis diagnosed by inhalation challenge. Ann. Allergy 47:449-452.

8. Greiner-Mai, E., F. Korn-Wendisch, and H. J. Kutzner. 1988. Taxonomic revision of the genus Saccharomonospora and description of Saccharomonospora glauca sp. nov. Int. J. Syst. Bacteriol. 38:398-405.

9. Greiner-Mai, E., R. M. Kroppenstedt, F. Korn-Wendisch, and H. J. Kutzner. 1987. Morphological and biochemical characterization and emended descriptions of thermophilic actinomycetes species. Syst. Appl. Microbiol. 9:97-109.

10. Grimont, F., and P. A. D. Grimont. 1986. Ribosomal ribonucleic acid gene restriction patterns as potential taxonomic tools. Ann. Inst. Pasteur Microbiol. 137B: $165-175$.

11. Hunter, I. S. 1985. Gene cloning in Streptomyces, p. 32. In D. M. Glover (ed.), DNA cloning, vol. 2. IRL Press, Oxford.

12. Kalakoutskii, L. V. 1964. A new species of the genus MicropolysporaMicropolyspora caesia n. sp. Mikrobiologiya 33:765-768.

13. Kauppinen, J., J. Pelkonen, and M.-L. Katila. 1994. RFLP analysis of $M y$ cobacterium malmoense strains using ribosomal RNA gene probes: an additional tool to examine intraspecies variation. J. Microbiol. Methods 19:261267.

14. Kim, E., H. Kim, S.-P. Hong, K. H. Kang, Y. H. Kho, and Y.-H. Park. 1993. Gene organization and primary structure of a ribosomal RNA gene cluster from Streptomyces griseus subsp. griseus. Gene 132:21-31.

15. Kim, S.-B. 1995. Polyphasic taxonomic studies on the genus Saccharomonospora and related taxa. Ph.D. thesis. University of Newcastle upon Tyne, Newcastle upon Tyne, United Kingdom.

16. Kim, S.-B., J.-H. Yoon, H. Kim, S. T. Lee, Y.-H. Park, and M. Goodfellow. 1995. A phylogenetic analysis of the genus Saccharomonospora conducted with 16S rRNA gene sequences. Int. J. Syst. Bacteriol. 45:351-356.

17. Kroppenstedt, R. M. 1985 . Fatty acid and menaquinone analysis of actinomycetes and related organisms, p. 173-189. In M. Goodfellow and D. E. Minnikin (ed.), Chemical methods in bacterial systematics. Academic Press, London.

18. Kurup, V. P. 1984. Thermophilic actinomycetes, their role in hypersensitivity pneumonitis, p. 145-159. In L. Ortiz-Ortiz, L. F. Bojalil, and V. Yakoleff (ed.), Biological, biochemical and biomedical aspects of actinomycetes. Academic Press, Orlando, Fla.

19. Lasker, B. A., J. M. Brown, and M. M. McNeil. 1992. Identification and epidemiological typing of chemical and environmental isolates of the genus Rhodococcus with use of a digoxigenin-labeled rDNA probe. Clin. Infect. Dis. 15:223-233.

20. Lechevalier, M. P., and H. A. Lechevalier. 1970. A critical evaluation of the genera of aerobic actinomycetes, p. 393-405. In H. Prauser (ed.), The Actinomycetales. Gustav Fischer Verlag, Jena, Germany.

21. Nonomura, H., and Y. Ohara. 1971. Distribution of actinomycetes in soil. X New genus and species of monosporic actinomycetes. J. Ferment. Technol. 49:895-903.

22. Richet, H. M., P. C. Craven, J. M. Brown, B. A. Lasker, C. Cox, M. M. McNeil, A. D. Tice, W. R. Jarvis, and O. C. Tablan. 1991. A cluster of Rhodococcus (Gordona) bronchialis sternal wound infections after coronaryartery bypass surgery. N. Engl. J. Med. 324:104-109.

23. Runmao, H. 1987. Saccharomonospora azurea sp. nov., a new species from soil. Int. J. Syst. Bacteriol. 37:60-61.

24. Runmao, H., C. Lin, and W. Guizhen. 1988. Saccharomonospora cyanea sp. nov. Int. J. Syst. Bacteriol. 38:444-446.

25. Skerman, V. B. D., V. McGowan, and P. H. A. Sneath (ed.). 1980. Approved lists of bacterial names. Int. J. Syst. Bacteriol. 30:225-420.

26. Soto, A., D. G. Pitcher, and F. Soriano. 1991. A numerical analysis of ribosomal RNA gene patterns for typing clinical isolates of Corynebacterium group D2. Epidemiol. Infect. 107:263-272.

27. Towner, K. J., and A. Cockayne. 1993. Molecular methods for microbial identification and typing. Chapman and Hall, London. 